TURIZAM

Volume 25, Issue 2

55-71 (2021)

ORIGINAL

SCIENTIFIC PAPER

\title{
The River Ganga and its Pollution- Tourists' Perception Visiting Ghats of Varanasi
}

\author{
Shikha Sharma ${ }^{\mathrm{A}}$, Madhoolika Agrawal ${ }^{\mathrm{A}}$ \\ Received: September 2020 | Accepted: May 2021 \\ DOI: $10.5937 /$ turizam25-23945
}

\begin{abstract}
The study attempts to assess tourists' (international, national and local) perceptions for polluted state of the river Ganga in Varanasi, plausible reasons for present status and their willingness to contribute towards river cleanliness. The Kruskal-Wallis analysis suggests variation in perception for pollution and river reverence across three categories of tourists. Tourists perceived the present status of river to be dirty and urged that it can only be improved by joint efforts of people and government. Further, positive response of tourists was observed for their involvement in cleanliness drive of the river Ganga via their willingness to pay and social activities.
\end{abstract}

Keyword: perception; pollution; reverence; tourists; willingness

\section{Introduction}

The river Ganga is a trans boundary river with its basin extending to Tibet, Nepal and Bangladesh (http://india-wris.nrsc.gov.in). At present this river is under threat and its pollution problems are debatable even at international forum. The river Ganga in India is an important tourists' destination. Tourists are drawn toward rivers in view of their beauty, serenity and adventure (Prideaux et al., 2009), but in India, it is predominantly the religious fervour and sentiments, which attract tourists to the river. If the movement of people to tourist destination can accelerate environmental degradation, tourist influx may also be affected by degrading environment of the tourist spot, thus sharing a vice-versa relationship. Ironically, river tourism has been neglected and apparently of little interest for researchers and academicians (Prideaux et al., 2009). Furthermore, studies evaluating the perception of tourists for degraded state of rivers also seem to be minimal.

Alley (2002) for the first time studied the perception of locals and tourists of Varanasi region in view of rising pollution in the sacred river Ganga and suggested a paradox between cultural significance of the river and rising pollution in the minds of people. Huberman (2012)

\footnotetext{
Institute of Science, Banaras Hindu University, Varanasi, India

Corresponding author: madhoo.agrawal@gmail.com
} 
explored riverfront of Varanasi as an iconic site from the international tourist perspective which attracts innumerable tourist. Buzinde (2014) studied the activities and experiences of tourists during Kumbh mela pilgrimage in Allahabad and found that the major activities of tourists were prayer, meditation, bathing and listening to spiritual preaching. Singh (2017) analysed the conditions of ghats in Varanasi and suggested that if managed effectively, the ghats offers enormous potential of employment generation. The impact of pilgrimage tourism was studied for the river Ganga during pre and post kanwar mela by Gagan et al. (2018) strategies for controlling religious touristic activities and promoting eco-pilgrimage was suggested. Luthy (2019) explored an ashram in Rishikesh for its role in raising environmental awareness via practicing of Ganga aarti, the author also suggested other activities such as mobile Ganga aarti, puppet show, classical dance performances and the role of religious institutions in raising awareness about river Ganga health. Gupta (2019) during economic assessment of tourism in Varanasi revealed that tourism in Varanasi has resulted not only in employment generation in the local community of Varanasi but also infrastructure development within city.

Implicit in this social research is the perception among tourists about the status of the tourist destination. Perception is a psychological phenomenon processing in individual human brain based on expectations, beliefs, prior knowledge and experiences, which undergo an assumption, based calculations to organise into a model internally, thus serving as guide to respond to external stimulus (Ingold, 200o). It is usually determined through interviews, surveys and participatory rural appraisal technique, thus eliciting people's assessment for the status of various environmental variables (Lund et al., 2010; Bird, 2009). Perception based methods have been widely used in conservation and management studies (Gallagher et al., 2015; Bennett, 2016). Therefore, this psychological phenomenon can be explicitly harnessed for improving the present polluted state of the river Ganga in India.

Among all the tourist destinations in Varanasi, riverfront ghats are frequently visited by both international and domestic tourists. This research, for the first time, attempts to assess the tourists'(international tourists, national tourists and local visitors)perceptions for polluted state of the river Ganga in Varanasi, in a view of acquired deep seated reverence for the river in heart and soul of tourists, especially Indians. The present work put forth the following objectives:

1. To assess the perception of tourists'viz. international tourist, national tourist and local visitors for present status and apportionment of blame for status of river Ganga.

2. To analyse attitude and perception of tourists to improve the river condition themselves or by supporting Government/NGO.

3. To understand perception of tourists for their feeling of reverence for the river even after realizing its polluted state.

\section{Materials and Methods}

\section{Study Area}

Varanasi (Banaras) harbours the western bank of river Ganga, situated 80.71m above mean sea level. Varanasi experiences tropical type of climate, with temperature varying from 5 to $45^{\circ} \mathrm{C}$ and annual rainfall of about 680 to $1500 \mathrm{~mm}$ during the month of July to September. The riverfront covering $6.8 \mathrm{~km}$ of crescent shape flowing river is lined by 84 ghats (Singh, 2011).The river Ganga flows in Varanasi from South to North. Varanasi holds a resident population of 3.148 
million persons (http://varanasi.nic.in/) and absorbs approximately 54,85,902 tourists annually (Regional tourist Office, Varanasi, 2016).

\section{Survey Sites}

The survey was confined to the ghats visited maximally i.e Dashawadeh ghat, Rajendra Prasad ghat, Ahilyabai ghat and Assi ghat. Ghats in Varanasi are stoned-cemented staircases with beautiful architecture built on top, which further lead its way into the river.

\section{Survey Method}

Survey was conducted from 2014 to 2016 via face to face interviews and emails by well-designed questionnaires. The questionnaire was pre-tested for its usefulness in providing valuable information with 30 participants.

\section{Sampling technique and sample size}

The 154 respondents were selected using purposive sampling. Purposive sampling "(also known as judgment, selective or subjective sampling) is a sampling technique in which researcher relies on his or her own judgment when choosing members of population to participate in the study" (https://research-methodology.net/).

\section{Questionnaire design}

The questionnaire-contained questions concerning the problem of water pollution and people perception for divinity of river Ganga. The questionnaire contained both open and closed type of questions. The first part dealt with general profile of respondents. The second section was designed to measure perception, awareness and knowledge of respondents about status of river Ganga in Varanasi, and apportionment of blame for its present status. The third section was designed to analyse the perception of respondents for their feeling of reverence towards river Ganga. The fourth section dealt with respondent's perception for future state of the river, apportionment of responsibility to improve the condition of river, their willingness to contribute towards cleanliness drive of the river.

\section{Statistics applied}

The data was subjected to normality check and in order to study the effects of demographic status on perception, Kruskal-Wallis and Mann-Whitney tests were performed using SPSS 20.

\section{Results and Discussion}

The old Indian scriptures regard the Ganga as the "Tirtharaj" and Varanasi, the city of Lord "Vishwanath" is blessed to be nurtured with this divine river. Among the respondents surveyed to know their perception about pollution and reverence of river Ganga in Varanasi, 13\% were international tourists from countries like Germany, Japan, America, Britain etc. 53\% were national tourists, $34 \%$ were locals (Table 1). The high percentage of national tourists visiting 
this place can be attributed to the 'cradle to death' and 'good to bad' association of every Indian (especially Hindu) to the river Ganga. Also, Gesler and Pierce (2000) stated Varanasi as Hindu sacred site.

\section{General socio-economic profile}

The gender ratio of the respondent was 1:0.97, with males constituting $51 \%$ and female $49 \%$, (Table 1), suggesting an equal participation of both the genders in the survey. The dominant religion among the respondents was Hinduism with $90 \%$, followed by Christianity $5 \%$ and $5 \%$ constituted other religions like Buddhist, Jainism and some respondent followed no religion (Table 1). As Varanasi, is the place harbouring Jyotrilinga of Lord Shiva with the river Ganga flowing close to it, large numbers of Hindus are attracted annually. According to Olsen and Timothy (2006) the kind of tourism flourishing in Varanasi is basically pilgrimage tourism stimulated by spiritual fervour.

Sixteen percent of respondents belonged to above sixty years age group, $19 \%$ between $40-60$ age group, and $65 \%$ between $20-40$ age group, suggesting that middle age group and adults showed more willingness to respond to the questionnaire. Fifty percent respondents belonged to single family, $47 \%$ to joint family and $3 \%$ to single parent family. In India, there persists the culture of living together with grandparents, who are valuable source of religious information and sentiments to flow into successive generations. Seventeen percent of respondents belonged to low income group, $17 \%$ to middle income group and $60 \%$ to high-income group and $6 \%$ objected to respond to this question (Table 1 ).

Table 1. Demographic profile of respondents $(N=154)$

\begin{tabular}{|l|c|l|c|}
\hline Characteristics & Percentage & Characteristics & Percentage \\
\hline Gender & 51 & Joint & 47 \\
\hline Male & 49 & Nuclear & 50 \\
\hline Female & 16 & Single Parent & 3 \\
\hline Age Groups & 19 & No School & \\
\hline 60 or above & 65 & Secondary & 1 \\
\hline $59-40$ & & Senior Secondary & 7 \\
\hline $39-20$ & 90 & Graduation & 9 \\
\hline Religion & 5 & Post-graduation & 53 \\
\hline Hindu & 5 & Other & 4 \\
\hline Christian & & Annual household income & \\
\hline Other & 13 & Not available & 6 \\
\hline Types of Tourist & 53 & Less than Rs.100000 & 17 \\
\hline International Tourists & 34 & Rs.100000-300000 & 17 \\
\hline National Tourists & & Greater than 300000 & 60 \\
\hline Locals & & & \\
\hline
\end{tabular}




\section{Pollution perception}

It has been long asserted by several researchers that Ganga Action Plan (GAP) succumbed as it lacked people participation, while for any development process to be a success, people participation is essentially required (Das, Tamminga, 2012; Baca, 2015). The participation of local people (who frequently visit the river) and tourists can only be ensured by sensitising them for an issue and knowing their perception and understanding for the state of the river.

During the survey, it was observed that $64 \%$ of respondents came to specifically visit the river and rest $36 \%$ respondents came for some other purposes such as educational, visiting other places in and around the city. For all those visiting Varanasi, it is the divinity and beauty of uniquely flowing crescent shaped river, which attracts them most (Rana, Singh, 2004). Sixty nine percent of respondents were visiting the river and ghats for the first time and $31 \%$ visited before. Among the respondents not visiting the place for first time, $9 \%$ visited the place second time, $34 \%$ more than 5 times and $43 \%$ visited regularly (Figure 1). Forty percent respondents found that the river has become dirty, $27 \%$ found it comparatively cleaner, $15 \%$ felt no change and $18 \%$ denied to answer when asked to comment on the river status compared to their earlier visits (Figure 2). However, various studies report that condition of river has not improved much in post-GAP phase (Rai, 2013).

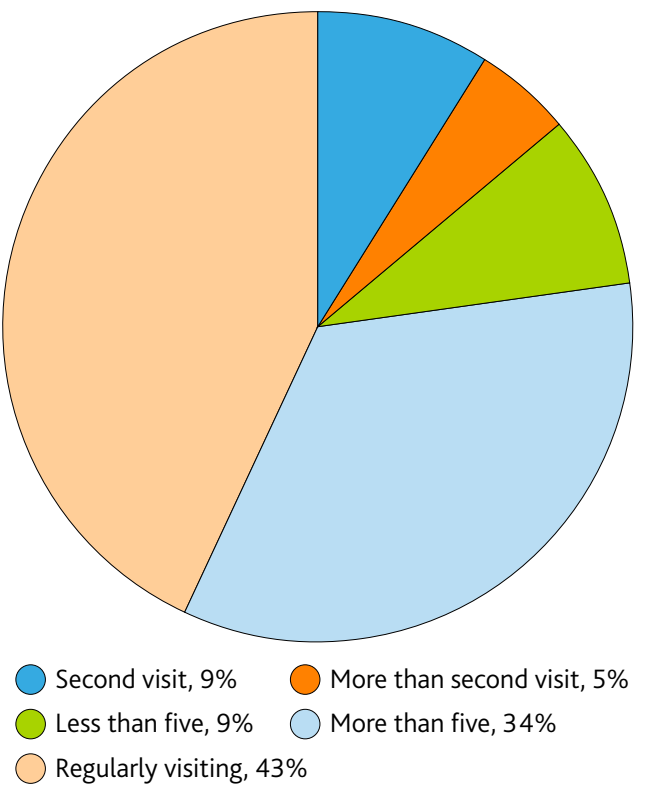

Figure 1. Number of times respondents' visiting the river Ganga

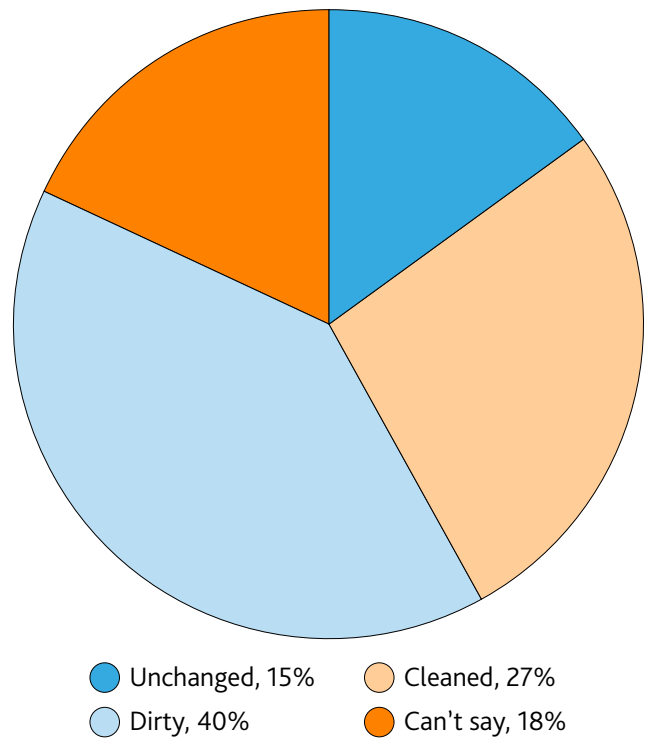

Figure 2. Respondents' perception for river health after their first visit

The Kruskal-Wallis test suggested that the respondents' perception for variable changes observed in river health during their subsequent visits varied significantly across variable categories of age and education status and tourists' types (Table 2). 40\% of international tourists felt that river has become dirty this perception of them can be attributed to their acquisition of information from internet before visiting the place and communications with local people during the time of visit. However, for $44 \%$ of national tourists' river has become dirty, on contrary $27 \%$ believed that river has become cleaned over the years. On the other hand, the percep- 
tion of locals visiting the river varied, as $33 \%$ considered river as dirty as before and $37 \%$ regarded it comparatively cleaner.

Table 2. Kruskal Wallis $p$ values of independent variables measuring perception for polluted state of river Ganga across different categories of dependent variables

\begin{tabular}{|l|c|c|c|c|c|}
\hline Attributes of Independent variables & Age & Gen* & Family type & Education & Tourist types \\
\hline Changes observed in river health & 0.000 & 0.730 & 0.165 & 0.002 & 0.002 \\
\hline What changes observed in river health & 0.000 & 0.431 & 0.254 & 0.208 & 0.001 \\
\hline Present status of river Ganga & 0.000 & 0.235 & 0.376 & 0.052 & 0.000 \\
\hline Responsibility of present status of river Ganga & 0.000 & 0.121 & 0.287 & 0.001 & 0.000 \\
\hline River Ganga polluted more in Varanasi & 0.000 & 0.313 & 0.003 & 0.061 & 0.000 \\
\hline River Ganga pollution from upstream district & 0.001 & 0.000 & 0.008 & 0.005 & 0.000 \\
\hline Pollution in river Ganga due to concrete ghat & 0.000 & 0.512 & 0.607 & 0.008 & 0.031 \\
\hline $\begin{array}{l}\text { Supporting the riparian zone encroachment by } \\
\text { people }\end{array}$ & 0.000 & 0.033 & 0.436 & 0.597 & 0.453 \\
\hline Concern for the present polluted state of river & 0.000 & 0.642 & 0.647 & 0.000 & 0.000 \\
\hline Want the river Ganga in future to be & 0.000 & 0.119 & 0.241 & 0.031 & 0.483 \\
\hline $\begin{array}{l}\text { Who can change the status of river Ganga in } \\
\text { future }\end{array}$ & 0.000 & 0.095 & 0.739 & 0.000 & 0.000 \\
\hline Whom to support more Government or NGO & 0.001 & 0.004 & 0.375 & 0.008 & 0.000 \\
\hline Initiating a change by themselves & 0.080 & 0.446 & 0.762 & 0.000 & 0.060 \\
\hline Modes of bringing change by themselves & 0.001 & 0.641 & 0.550 & 0.180 & 0.038 \\
\hline Willingness to pay for cleanliness of river & 0.000 & 0.166 & 0.667 & 0.000 & 0.127 \\
\hline
\end{tabular}

*-Mann Whitney Test, level of significance, $p<0.05$

The major attraction for tourists in Varanasi during the survey was Ganga arti (39\%), followed by historical architecture $(21 \%)$, river site view $(12 \%)$, boat ride $(6 \%)$, festive fervour of Indians (5\%), some other places of interests $(4 \%)$ and $13 \%$ had liking for all the stated options (Figure 3). Rana and Singh (2004) asserted that irrespective of the purpose of visit, be it national or international tourists, the places of tourist interests in Varanasi are mostly riverfront scenery of ghats and boating in the river. On the contrary, Parry (1994) viewed Varanasi as a place with death booming industries. However, in the present study it seems that people are more interested in witnessing the mesmerising Ganga arti at ghats, and the variable synchronistic moves of pandits performing arti (religious hymns).

Respondents views varied when enquired about the present status of the river Ganga as $43 \%$ respondents found the river very dirty, $26 \%$ dirty, $1 \%$ were unable to judge the river condition and surprisingly 30\% considered present status to be clean (Figure 4a).The river Ganga was categorised dirty by Alley (2002) based on his interaction with people of Varanasi. This trend of response suggests variations in perception among tourists due to their visual perception or acquisition of knowledge via television and newspapers. However, the response for perception of present status of river varied significantly with variable categories of age of respondents and tourist types (Table 2). As $30 \%$ and $70 \%$ of international tourists believed river to be dirty and very dirty respectively. However, $41 \%$ of locals felt river presently is clean, $37 \%$ felt river to be dirty, $18 \%$ regarded river status to be very dirty and $4 \%$ as river to be very clean, this perception can probably due to their comparison and experience for the river state over the years as they are regular visitors to the place. Among the national tourists $29 \%$ felt river to be clean, $49 \%$ felt river as dirty and $22 \%$ felt river as very dirty. 


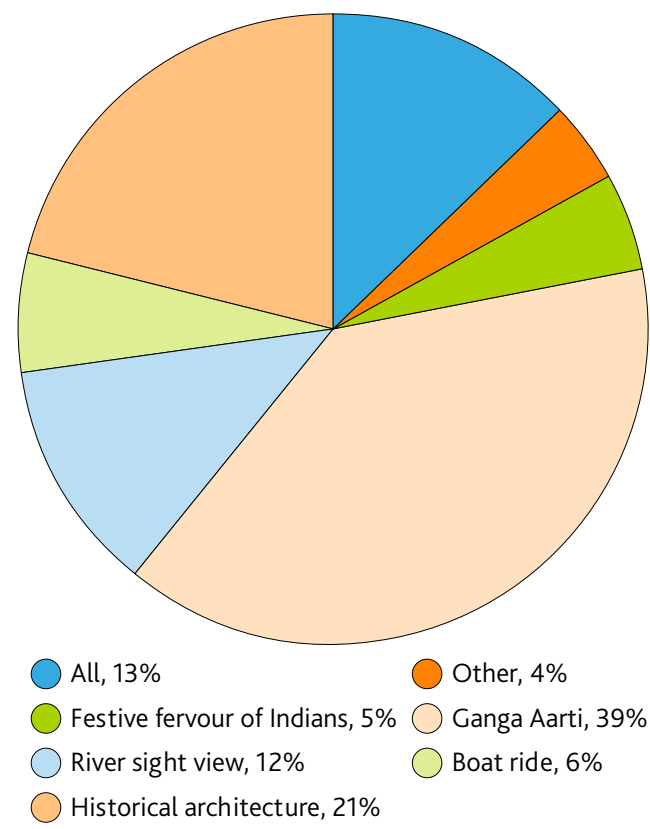

Figure 3. Variations in liking of respondents for major attractions of riverfront

Alley (1994) acclaimed long back that Ganga remains in the sorry state just because of apportionment of blame between locals, tourists and government officials. Similar observations were recorded during the present study while interrogating the respondents for blaming people responsible for polluted state of the river. Seventy three percent of respondents felt that present state of the river is attributed to negligence by local people, local government, central government and tourists all together. Among them highest rated responsibility of 10 was given to local people and local government (Figure $4 \mathrm{~b}$ ). Thirteen percent of the total respondents blamed local people, $4 \%$ to central government, $3 \%$ to local government and $2 \%$ to tourists solely for the polluted state of the river Ganga (Figure 4b). However, this query of rating the responsible authority out of 10 was responded by only $56 \%$ and other $44 \%$ showed their in convenience to answer such question probably thinking it to be a time taking procedure. A signifi-

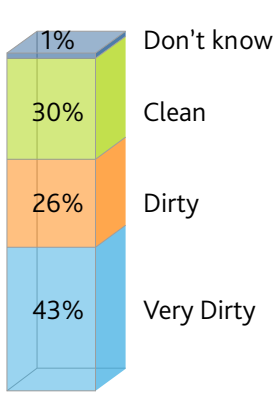

Present status of the river

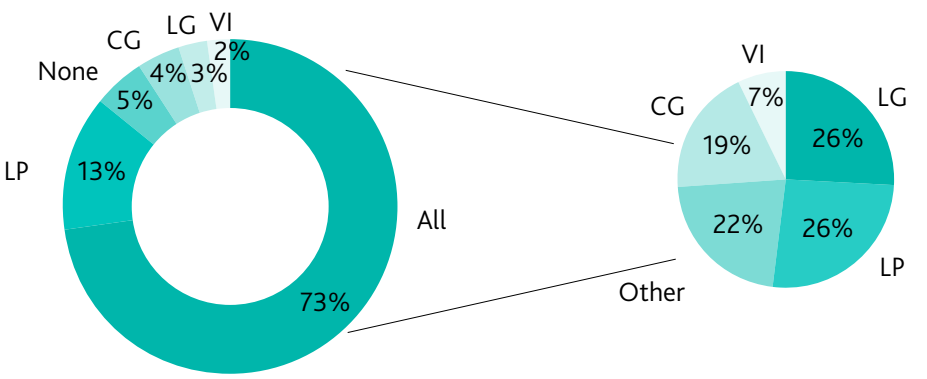

Apportionment of blame for its polluted status (LP - Local People, CG - Central Government, LG - Local Government, VI - Visitors)

Figure 4. Respondents' perception for (a) present status of the river (b) apportionment of blame for its polluted status.(LP-Local People, CG-Central Government, LG-Local Government, TO-Tourists) 
cant variation was observed among the variable categories of age and education of respondents for apportionment of blame for polluted state of the river Ganga (Table 2).

Further, respondents were asked whether Ganga enters after becoming polluted from other cities or experiences the pollution in Varanasi. Sixty nine percent respondents felt that Ganga enters Varanasi in a polluted form from other upstream districts, $13 \%$ felt no and $18 \%$ failed to answer this question (Figure 5). This response varied significantly with different categories of age, gender, family type, education of respondents and tourists' types (Table 2). Among international tourists $40 \%$ of them felt that river is polluted from upstream district, whereas $20 \%$ felt that the river is not polluted from the upstream district, moreover, $40 \%$ showed their inconvenience to answer this question as they were not aware of the cities through which the river crosses. Among locals $89 \%$ felt river to be polluted from the upstream and $7 \%$ considered river to be not polluted from upstream. Fifty eight percent of national tourists felt river was polluted from upstream district, $17 \%$ felt river to be not polluted from upstream district and $25 \%$ were unable to answer this question.

However, $41 \%$ respondents felt that Ganga is also being polluted in Varanasi apart from being entering polluted from other upstream districts, $38 \%$ felt that not many pollutants are added to river in Varanasi, and 21\% don't know as to how the situation stands (Figure 5a). The responses of tourists showed variability among three categories of tourists. As $50 \%$ of the international tourists believed river to be polluted more in Varanasi, 50\% were of notion that river is not polluted in Varanasi. Among local $30 \%$ believed river to be polluted more in Varanasi, $63 \%$ were of notion that river is not polluted in Varanasi and $7 \%$ were unaware of the question. On the other hand $49 \%$ of national tourists felt river is polluted more in Varanasi, $29 \%$ believed river being not much polluted in Varanasi and 22\% were unable to perceive the situation of river Ganga in Varanasi. Respondent's response for Ganga being polluted more in Varanasi varied significantly with different categories of age, family and tourists type (Table 2). Maximum respondents thought that the pollutants especially flowing down from Kanpur are responsible for polluted state of the river. A scientific report states that the discharge (in MLD) received by the river Ganga from various drains of upstream cities in sequential order are 600

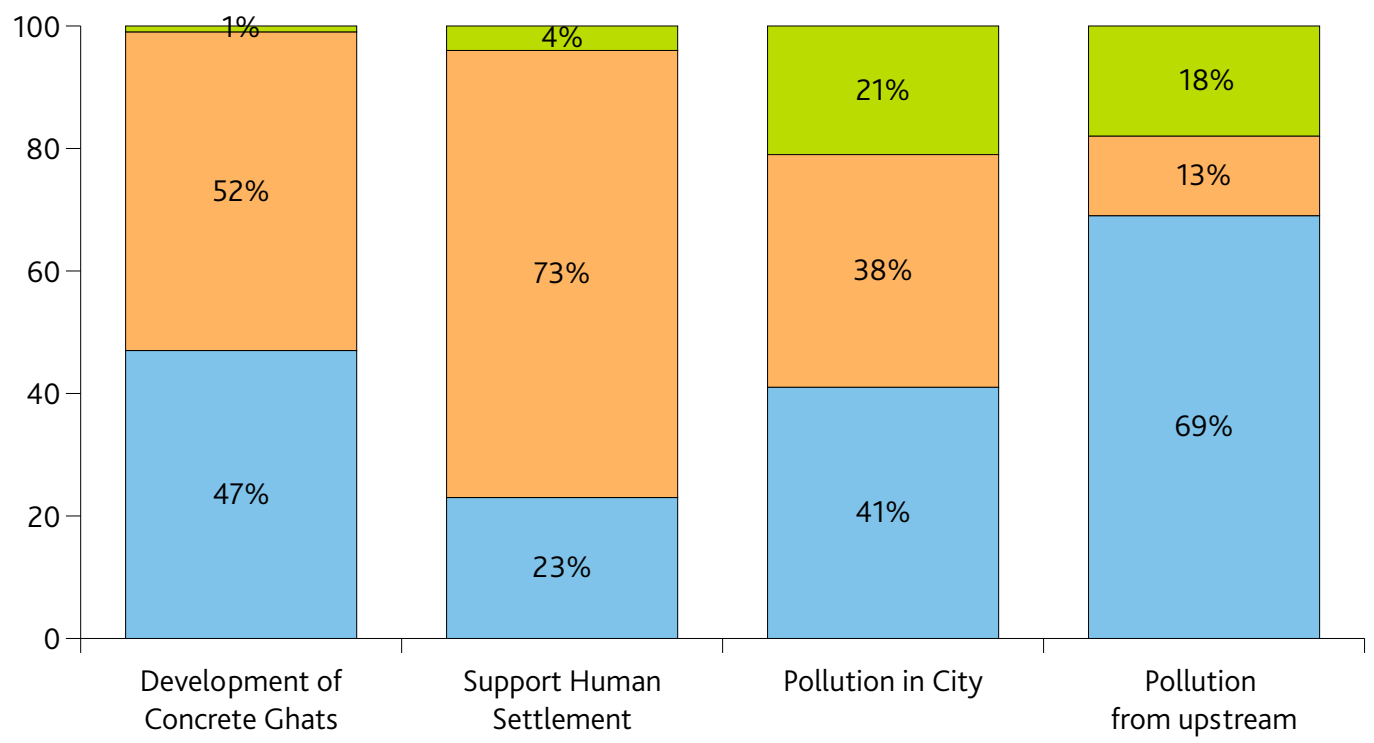

Figure 5a. Respondents' perceptions for different reasons of pollution in the river 


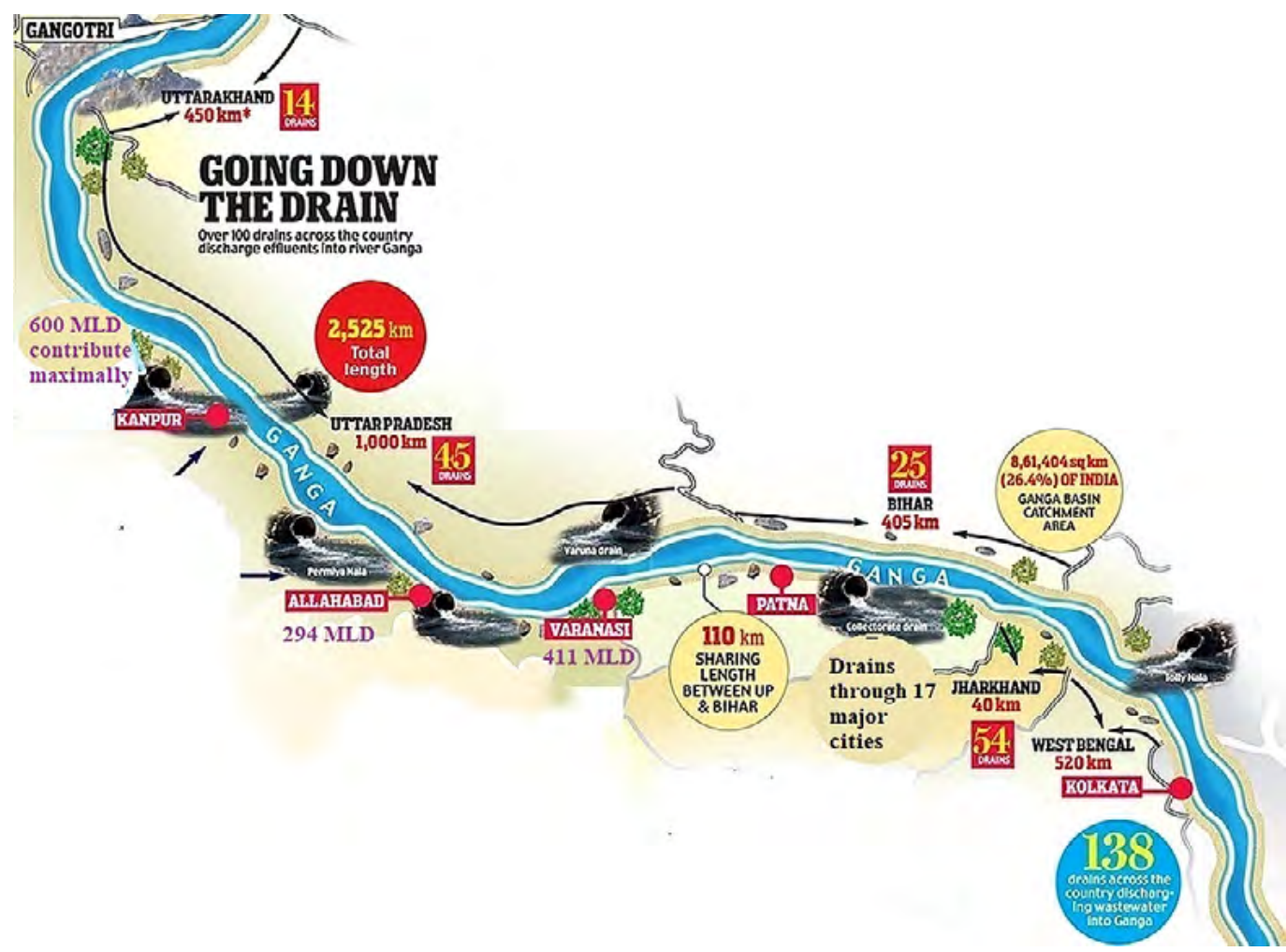

Figure 5b. Pollutants input into the river Ganga from varied cities (Source: https://www.dailymail.co.uk/, with modification)

from Kanpur, 78 from Unnao, 1491 from Fatehpur-Raibareilly, 294 from Allahabad, 149 from Mirzapur and 411 from Varanasi (CSE, 2014) (Figure 5b).

Varanasi is the city where riparian vegetation is negligible and city is witnessing ever rising urbanisation (Sharma et al., 2016). In next attempt respondents were analysed for their view to encroachments near river bank. Forty seven percent of respondents felt that development of concrete Ghats contributed to polluting the river (Figure 5a). However, $52 \%$ felt ghats to be contributing no pollutants into the river and $1 \%$ showed their ignorance to answer this question (Figure 5a). Among the international tourists $60 \%$ felt development of concrete ghat to be contributing pollutants into the river and $40 \%$ were against this view, among locals $48 \%$ felt ghats to be contributing pollutants into the river and $48 \%$ felt ghats were not contributing pollutants and $4 \%$ were unable to perceive ghats as contributors of pollutants into river, among national tourists $44 \%$ felt development of ghats near river to be contributing towards river pollution and $56 \%$ were against this view. This perception showed significant variation with variable categories of age, education and tourists' types of respondents (Table 2). However, 73\% respondents were against the riparian zone (near river bank) encroachment by people of river Ganga while $23 \%$ were in favour and $4 \%$ respondents could not clearly make out their response (Figure $5 \mathrm{a}$ ). Among international tourists $40 \%$ supported riparian zone encroachment by people, however $81 \%$ of local visitors and $73 \%$ of national were against riparian zone encroachment by people. This perception varied significantly with age and gender of respondents (Table 2). Similar issues of human settlement along rivers have been addressed and adjudged to be problems for river health by Soemarno (2010) for 
the river Kali Surabaya in Indonesia, Normelani et al. (2015) for the Barito river in Indonesia and Baca (2015) in the river Ganga in India.

After adjudging the respondents' knowledge for the polluted state of the river Ganga, the respondents were examined to know their concern about river pollution. Ninety one percent of respondents showed their concern towards river pollution. This suggests high level of awareness among respondents for pollution and their sensitivity for rising pollution in Ganga. This perception also varied significantly with different categories of age and education of respondents (Table 2).

\section{Perception for deep reverence for river Ganga}

Even though maximum percentage of respondents regarded the river to be dirty and very dirty, $60 \%$ have taken bath in the river water comprising of national tourists and locals (Figure 6) and no foreign tourists surveyed took bath in the river. Bathing in river Ganga seems to be mandatory for many Indians as it has been mentioned in our scriptures and passed down through legacies that bathing in these holy waters frees us from our trespasses. Therefore, even when the pollutants are visibly floating in the river, a large crowd of people can be seen bathing near ghats. During the festive days and months like Ganga Dussehra, shivratri, poornima, savan, kartik, etc. the main ghats remain flooded with people.Almost 2,00o,ooo people bathe in the Ganga river each day and 60,00o in Varanasi (Hamner et al., 2013). Hamner et al. (2006) reported significant relationship between usage of Ganga water for various purposes such as bathing, laundry, washing utensils and brushing teeth with the occurrence of waterborne/enteric diseases. However, $83 \%$ of respondents during the survey have not drunk river water (Figure 6), among which none of the international tourists drank river water. This trend of results suggested that while the percentage of respondents bathing was more, still respondents avoided to drink the water due to several reasons like stinking and bad smell, dirty view, presence of pollutants like metals, risk of having bad health effects, etc.

Gangajal is regarded like 'Amrit' and life saviour in many Hindu scriptures and often found in many homes in India because of its usage in various religious ceremonies. On enquiring whether respondents take Gangajal to their home or not, $78 \%$ respondents answered positively (Figure 6), however all the international tourist answered negative to this question. This probably can be due to the divinity and sanctity associated with taking Gangajal to home, to be used in various religious ceremonies and rituals which is religion and nationality specific. The irony to above finding is that even when maximum respondents took Gangajal to their homes they still suspected its purity. Of all respondents $47 \%$ said Gangajal is pure and 53\% said no (Figure 6), among which all international respondents doubted the purity of river Ganga in view of rising pollution. Eck (1982) remarks that "question here is not of purity of Ganges, but the cultural understanding of what it means for something to be pure or impure clean or dirty".

The Ganga may be a river for people overseas, serving as a water source for irrigation, drinking and generating electricity, but for people in India its "Ganga Ma". During the present study, it was seen that while talking $75 \%$ of respondents referred the river as Ganga Ma, $22 \%$ refer Ganga and 3\% refer simply a river (Figure 6). Among the international tourists only $30 \%$ of them called river as "Ganga Ma" which probably can be the outcome of their influence by the Indian society during their visits. These observations showed the deep reverence especially among the Indian tourists for river Ganga. Lochtefeld (2010) explained the difference of referring the river as Ganges and Ganga, Ganges means a moving contaminated and polluted water body, whereas Ganga means a goddess for purifying and to be worshipped. 

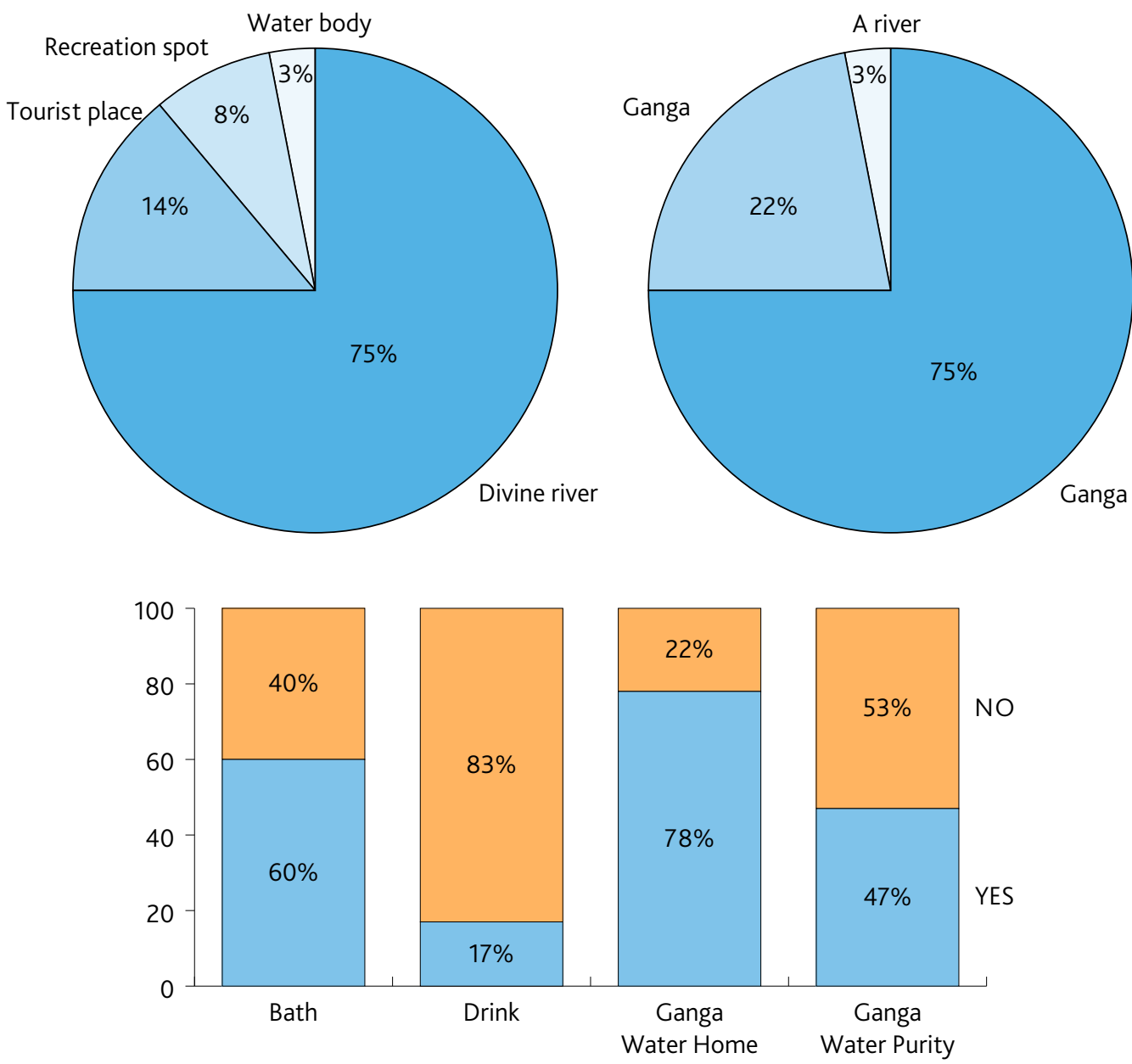

Figure 6. Perception among tourists for their feeling of reverence for the river

Seventy five percent of respondents observed the river to be as divine river, $14 \%$ as a tourist place to visit, $8 \%$ a place for recreation and $3 \%$ consider it simply a water body (Figure 6). Other than international tourists who visited the river as a place of recreation and tourists destination, the national tourists were seen engaging in achman (the process of taking a sip of pious Ganga water before performing any religious activities), offering prayers and seeking moksha (beatification),which presumes to be the reason for such divine perception of tourists for the river Ganga. Rana and Singh (2004) also observed that main activity of domestic tourists visiting Varanasi is religious practices, while foreign tourists are inclined more towards recreation. Gagan et al. (2018) associated the river Ganga with pilgrimage kind of tourism. It has been found that to most of the people the Ganga basin appears to be a part of the cosmic order of symbolic and practical importance (Alley, 2002). Drew (2011) also pointed towards the deep reverence of people for the river Ganga claiming the disappearance of river will lead to simultaneous disappearance of mankind.

The Kruskal-Wallis test suggested that all the attributes measuring perception of reverence for river Ganga varied differently across variable categories of age, gender, family type, education and present status and among three categories of the tourists (Table 3). The perception of 
respondents to observe river, refer river and bath in the river was same across variable categories of respondents analysing the present status of river and education status (Table 3 ). This suggested that respondents pay homage and regard to this Indian River with deep reverence, irrespective of the present status of river which may be dirty or very dirty. Also, the respondents' education status doesn't minimize their attitude to regard the river to be holy and divine. Further the three categories of tourists' viz. international tourists, national tourists and locals, showed variable response towards considering the divinity and sanctity of the river Ganga, with Indian tourist paying great homage to the river and considering it to be Goddess and international tourists considering river to be only source of water and riverfront as tourists' hotspot for vacationing.

Table 3. Kruskal Wallis $p$ values of independent variables measuring the perception of reverence for river Ganga across different categories of dependent variables

\begin{tabular}{|l|c|c|c|c|c|c|}
\hline $\begin{array}{l}\text { Attributes of } \\
\text { Independent variables }\end{array}$ & Age & Gender & Family type & Education & $\begin{array}{c}\text { Present } \\
\text { status }\end{array}$ & $\begin{array}{c}\text { Tourists' } \\
\text { types }\end{array}$ \\
\hline Observe river & 0.000 & 0.064 & 0.004 & 0.477 & 0.178 & 0.040 \\
\hline Refer river & 0.001 & 0.664 & 0.001 & 0.939 & 0.135 & 0.000 \\
\hline Bath in river & 0.000 & 0.015 & 0.013 & 0.079 & 0.170 & 0.035 \\
\hline Drink river water & 0.000 & 0.003 & 0.205 & 0.001 & 0.002 & 0.000 \\
\hline Gangajal purity & 0.000 & 0.880 & 0.865 & 0.033 & 0.000 & 0.000 \\
\hline Take Gangajal to home & 0.001 & 0.043 & 0.000 & 0.000 & 0.002 & 0.000 \\
\hline
\end{tabular}

However, the people tendency, to drink Ganga water, to regard it to be pure and to take Ganga water home varied after visualising the status of river (Table 3). More educated respondents were more aware of harmful effects of pollutants. During the survey it was also observed that respondents stated their preference to take Gangajal from upstream area like Haridwar where the river is less polluted.

\section{Perception for future state of river Ganga}

Seventy four percent of respondents wanted the river to be very clean, while $26 \%$ wanted the river to be clean when asked for their future perception about status of river Ganga (Figure 7a). The perception varied significantly with age and education categories but was same among three categories of tourists (Table 2). Of all the tourists $70 \%$ of international tourists, $71 \%$ of national tourists and $78 \%$ of locals wanted the river Ganga to be very clean in future (Figure 8 ).

When apportionment of responsibility for future state of river Ganga was enquired $82 \%$ respondents said that it can only be possible by the combined efforts of local people, local government, central government and tourists (Figure $7 \mathrm{~b}$ ). However, $9 \%$ felt that it's the responsibility of local people, for $3 \%$, it's the responsibility of local government, for $1 \%$ central government and $5 \%$ felt that nobody can change the status of the river Ganga. Among the respondents who regarded the joint efforts to be a best measure for cleaning the river, only $61 \%$ respondents responded to rated question. The maximum rating out of 10 was given to local people, suggesting that responsible efforts by locals can help in improving the condition of the river (Figure $7 b)$. This perception varied significantly with age, education and among three categories of the tourists. Das and Tamminga (2012) also discussed the participation of local people in implementing various programmes towards cleaning the river Ganga. The maximum percentage of 

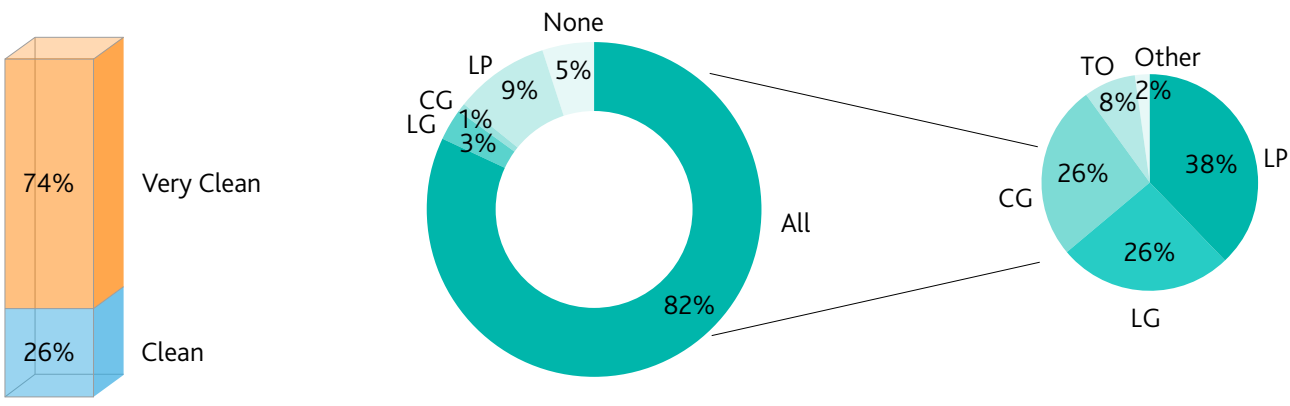

Apportionment of responsibility for its cleanliness

(LP - Local People, CG - Central Government, LG - Local Government, VI - Visitors)

Figure 7. Respondents' perception for (a) future state of the river and (b) apportionment of responsibility for its cleanliness (LP-Local People, CG-Central Government, LG-Local Government, TO-Tourists

international tourists $(70 \%)$, locals $(63 \%)$ and national tourists $(80 \%)$ believed that very clean status of river can only be achieved by the joint efforts.

Indian government both at state and central levels is working for cleanliness drive of the river Ganga. There is Ministry of Water Resources, River Development \& Ganga Rejuvenation in India dedicated completely to restore the river Ganga. Also, there are many NGOs work-

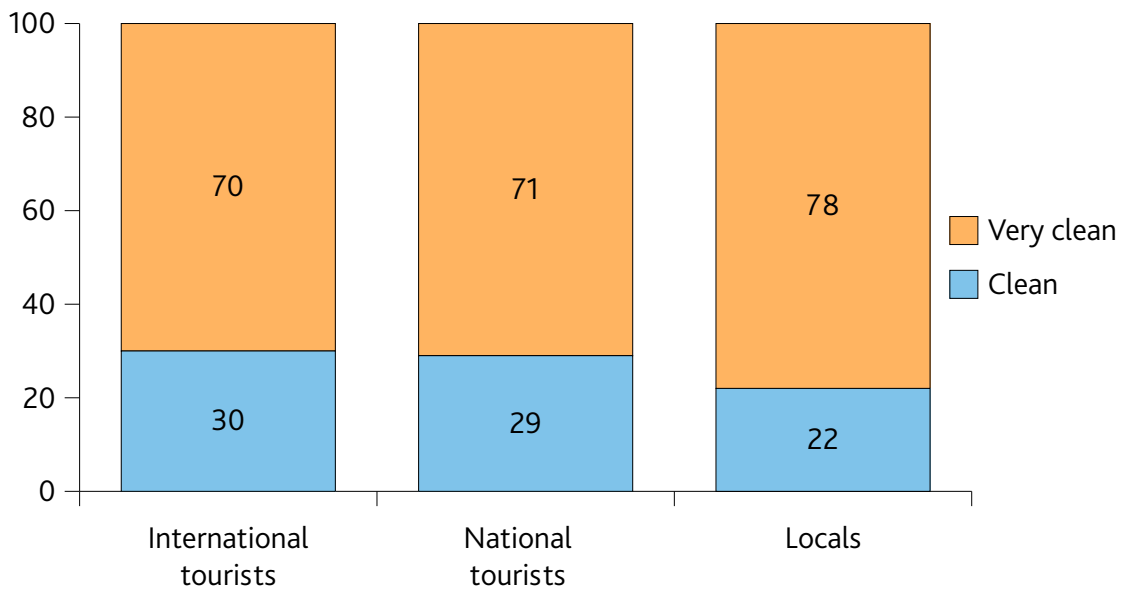

Figure 8. Variable responses of three categories of tourists for future state of river

ing in similar directions. When respondents were asked for their support for cleanliness drive of the river Ganga, $69 \%$ respondents wished to support government more than NGO (Figure 9a). Many river restoration programmes have been a success by government-people partnership (Weng, 2005). This perception varied significantly with age, gender, education and tourist' types. $60 \%$ of international tourists wished to support government for cleanliness drive of river Ganga, $67 \%$ national tourists showed their support to government and 33\% to NGO, on the other hand $73 \%$ locals supported government and $27 \%$ supported NGO.

Other than efforts to improve river health, respondents were asked for their interest to initiate a change for the river Ganga. Ninety-three percent respondents answered positively to initiate change by themselves, however, $4 \%$ said no and $3 \%$ respondents showed their disinterest in such kind of activities. The respondents' perception for initiating a change varied signif- 
icantly with their education level, but was same across variable categories of tourist (Table 2). Further, $30 \%$ respondents showed their interest to bring changes economically, $64 \%$ by some social activities, while $6 \%$ were in dilemma as to how they can bring about a change (Figure $9 \mathrm{~b}$ ). This perception varied significantly with different categories of age and tourists types. Among the international tourists $30 \%$ of them wanted to bring change economically, $30 \%$ wanted to do it via some social activities and $40 \%$ by some other means. However, $81 \%$ of local people wanted to bring change by social activities and among national tourists $39 \%$ can do it economically and $56 \%$ via some social activities. This suggested the interest of national people to solve the pollution problems of river Ganga via some social activities. It has been observed that social activities have helped improving the river condition in Europe (Mostert et al., 2007).

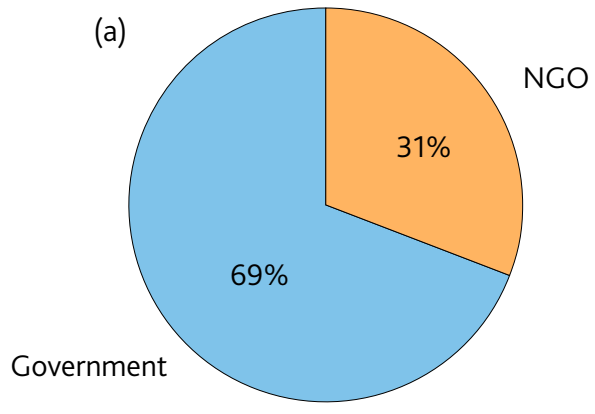

(b)

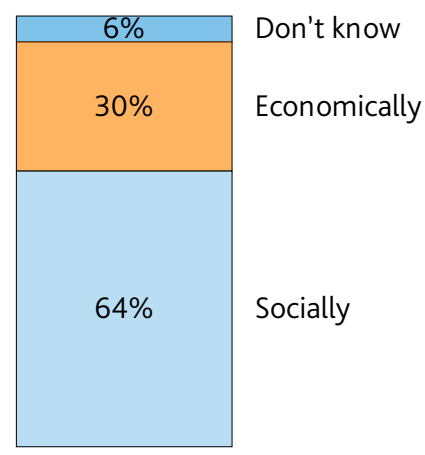

Figure 9. Respondents' perception for (a) Supporting government and NGO (b) their Mode of initiating for cleanliness drive of the river Ganga

Apart from the way respondents wanted to change the river, respondents were asked for their willingness to pay for cleanliness drive of the river Ganga monthly. 38\% respondents showed their willingness to pay within Rs. 80-100, $27 \%$ within Rs. 10-30, $12 \%$ within Rs. 30-50, $4 \%$ within Rs. $50-80$ and $9 \%$ wanted to pay more than Rs. 100 . However, $10 \%$ criticised for such payment for cleanliness drive due to the perception that their money will not be utilised effectively and some felt that they already pay taxes (Table 4). This perception varied significantly with age and education status of respondents. Imandoust and Gadam, (2007) reported an average willingness to pay Rs. 17.75 per month per family for river water quality of Pavana river in Pune, India.

Irrespective of the polluted state of the river Ganga, 94\%respondents showed their positive response to visit the river again and $6 \%$ showed no interest in visiting the river again. This suggests the deep reverence and interest within the tourists to view the majestic beauty of the river and ghats in Varanasi. Further, 90\% respondents felt that they are going to recommend other people to visit this river and 10\% answered negatively. Rajeev and Shyju (2008) reported that $80 \%$ of tourists prefer to visit Varanasi again because of Ghats, river Ganga and life style of people which attract more foreign tourists. 
Table 4. Respondents willingness to pay (WTP) for cleanliness drive of river Ganga

\begin{tabular}{|c|c|c|}
\hline № & Amount to be paid (Rupee) & Percentage of respondent \\
\hline 1. & $10-30$ & 27 \\
\hline 2. & $30-50$ & 12 \\
\hline 3. & $50-80$ & 4 \\
\hline 4. & $80-100$ & 38 \\
\hline 5. & More than 100 & 9 \\
\hline 6. & Don't want to pay & 10 \\
\hline
\end{tabular}

\section{Conclusion}

The tourists international, national and locals visiting the river visualised the present status of the river to be dirty and laid the burden of responsibility on local people and local government. The respondents strongly opposed the development of human settlement near river bank and regarded it to be a potent source of pollutants into the river. The perception of the local visitors and national tourists for polluted state of the river was contradictory to their feeling of reverence for the river. Even when they felt river to be polluted, still, most of them had bath, took Gangajal home and regarded river to be divine and called it as Ganga Ma. However, international tourist considered river to be polluted and simply a source of flowing water independent of their feeling of reverence for the river.

The expectations of those visiting Varanasi for the future status of the river was to be very clean and they believed that efforts from local people will lead to such achievement. The tourists both international and national showed their interest to support Indian government. The tourists showed positive response towards their involvement in cleanliness drive of the river Ganga both socially and economically (via willingness to pay). The tourists were very sensitive to the present polluted state of the river Ganga in India and urged to policy makers to involve people associated with the river because in the end 'Ganga is by the people, to the people, and for the people'.

\section{References}

Alley, K.D. 1994. Ganga and Gandagi: Interpretations of pollution and waste in Benaras. Ethnology 33(2), 127-145.

Alley, K.D. 2002. On the banks of the Gangā: When wastewater meets a sacred river. University of Michigan Press.

Baca, E.A. 2015. The Ganges river: symbology, sustainability, and the confluence of cultural and fluvial connectivity (Doctoral dissertation).

Bennett, N. J. 2016. Using perceptions as evidence to improve conservation and environmental management. Conservation Biology 30(3), 582-592.

Bird, D. K. 2009. The use of questionnaires for acquiring information on public perception of natural hazards and risk mitigation-a review of current knowledge and practice. Natural Hazards and Earth System Sciences 9(4),1307-1325.

Bulmer, M. (Eds.) 2004. Questionnaires. Sage Publications, London. 
Buzinde, C. N., Kalavar, J. M., Kohli, N., Manuel-Navarrete, D. 2014. Emic understandings of Kumbh Mela pilgrimage experiences. Annals of Tourism Research 49, 1-18.

CSE, Centre for Science and Environment. 2014. "Can we save Ganga" in Down to earth. 31 July 2014, fortnightly magazine. New Delhi India, (http://www.downtoearth.org.in/).

Das, P.,Tamminga, K. R. 2012. The Ganges and the GAP: An assessment of efforts to clean a Sacred River. Sustainability 4(8), 1647-1668.

Drew, G. 2011. Ganga is Disappearing: Women, Development, and Contentious Practice on the Ganges River (Ph. D dissertation, University of North Carolina at Chapel Hill).

Eck, D. L. 1982. Banaras, city of light. Columbia University Press.

Elhance, D.N, Elhance, V., Aggarwal, B.M. 2009. Fundamentals of Statistics (LIIIrd Rep.ed.). Kitab Mahal, 22-A, Sarojini Naidu Marg, Allahabad.

Gallagher, A.J., Cooke, S.J., Hammerschlag, N. 2015. Risk perceptions and conservation ethics among recreational anglers targeting threatened sharks in the subtropical Atlantic. Endangered Species Research 29(1),81-93.

Gagan, M., Kumar, A., Bhatnagar, S., Kumar, A., Nayak, A., Kumar, P. 2018. Repercussions of tourism on water quality of River Ganga in lower Himalayas. International Journal for Environmental Rehabilitation Conservation 1, 90 - 103.

Gangwar, K. K., Joshi, B. D. 2008. A preliminary study on solid waste generation at Har Ki Pauri, Haridwar, around the Ardh-Kumbh period of sacred bathing in the river Ganga in 2004. The environmentalist 28(3),297-300.

Gesler, W. M., Pierce, M. 20oo. Hindu Varanasi. Geographical Review 9o(2), 222-237.

Gupta, S. K. 2019. Destination Evaluation and Tourism Economic Impact Assessment: A Case Study of Varanasi. Journal of the Gujarat Research Society 21(14), 1446-1456.

Hamner, S., Damon P., Michelle W., Gopal P., Rajesh K. M., Veer B. M., Catherine P., Timothy E. F. 2013. Sewage pollution of the River Ganga: an ongoing case study in Varanasi, India. River Systems 20(3), 157-167.

Hamner, S., Tripathi, A., Mishra, R. K., Bouskill, N., Broadaway, S. C., Pyle, B. H., Ford, T. E. 2006. The role of water use patterns and sewage pollution in incidence of water-borne/ enteric diseases along the Ganges river in Varanasi, India. International Journal of Environmental Health Research 16(2), 113-132.

Huberman, J. 2012. Ambivalent encounters: childhood, tourism, and social change in Banaras, India: Rutgers University Press.

Huntington, H.P.20oo. Using traditional ecological knowledge in science: methods and applications. Ecological Applications 10(5), 1270-1274.

Imandoust, S. B., Gadam, S. N. 2007. Are people willing to pay for river water quality, contingent valuation. InternationalJournal of Environmental Science \& Technology 4(3), 401-408.

Ingold, T. 200o. The perception of the environment: essays on livelihood, dwelling and skill. Psychology Press.

Lochtefeld, J. 2010. God's gateway: Identity and meaning in a Hindu pilgrimage place. Oxford University Press.

Lund, J.F., Balooni, K., Puri, L. 2010.Perception-based methods to evaluate conservation impact in forests managed through popular participation. Ecology and Society15(3), 5.

Luthy, T. 2019. Bhajan on the Banks of the Ganga: increasing environmental awareness via devotional practice. Journal of Dharma Studies 1(2), 229-240.

McDonald, J. H. 2009. Handbook of biological statistics. Sparky House Publishing Baltimore, Maryland. 
McDonald, J.H. 2014. Handbook of Biological Statistics (3rd ed.). Sparky House Publishing, Baltimore, Maryland.

Mostert, E., Pahl-Wostl, C., Rees, Y., Searle, B., Tàbara, D., Tippett, J. 2007. Social learning in European river-basin management: barriers and fostering mechanisms from 10 river basins. Ecology and Society 12(1),19.

Nachar, N. 2008. The Mann-Whitney U: A test for assessing whether two independent samples come from the same distribution. Tutorials in Quantitative Methods for Psychology 4(1), 13-20.

Normelani, E., Djati, M.S., Hidayat, T., Hakim, L. 2015. Tourist profiles and perception as a basic planning for sustainable tourism development Lok Baitan Floating Market, South Kalimantan. Journal of Environmental Science, Toxicology and Food Technology 9(11), 11-16.

Olsen, D. H., Timothy, D. J. 2006. Tourism and religious journey. In D.J. Timothy \& Olsen, D.H (Eds.) Tourism, religion and spiritual journeys. USA and Canada: Routledge press, 1-22.

Parry, J. P. 1994. Death in Banaras. Cambridge University Press.

Prideaux, B., Timothy, D.J., Cooper, M. 2009. Introducing river tourism: Physical, Ecological and Human aspects. In B. Prideaux \& M. Cooper (Eds.) River tourism. MPG Books Group, U.K, 1-22.

Rai, B. 2013. Pollution and conservation of Ganga river in modern India. International Journal of Scientific and Research Publications 3(4), 1-4.

Rajeev, Dr. P.V., Shyju, Dr. P.V. (2008). Key Issues in Visitor Experience and Tourism Development - A Study of Varanasi, Conference on Tourism in India - Challenges Ahead, 15-17 May 2008, Part XI - Health, Spiritual and Heritage Tourism, IIMK 495-501.

Rana, P. S., Singh, R. P. 2004. Behavioural Perspective of Pilgrims and tourists in Banaras (Kashi) India. The Tourist-A Psychological Perspective. New Delhi: Kanishka Publisher

Regional tourist Office Varanasi., 2016, Uttar Pradesh Tourism, Government of UttarPradesh, India (Obtained the data).

Sharma, S., Roy, A., Agrawal, M. 2016. Spatial variations in water quality of river Ganga with respect to land uses in Varanasi. Environmental Science and Pollution Research 1-11.

Singh, R.P.B. 2011. Varanasi, India's cultural heritage city: contestation, conservation \& planning. In R.P.B Singh, (Eds.), Heritagescapes and cultural landscapes. Planet Earth \& cultural understanding series (pp. 205-254). New Delhi: Shubhi Publications.

Singh, D. 2017. Ghats that never sleep- life of thousands Varanasi, Uttar Pradesh. Editorial Board 6(12), 1.

Soemarno, I. 2010. A 'Simple'Solution Proposal for Riverbank Settlement Problems in Surabaya. Environment and Urbanization Asia 1(2), 209-222.

Weng, C.N. 2005. Sustainable management of rivers in Malaysia: Involving all stakeholders. International Journal of River Basin Management 3(3),147-162.

http://www2.unwto.org/ (12 July 2016.)

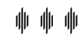

http://india-wris.nrsc.gov.in (12 July 2016.)

unwto.org (18 July 2016.)

http://varanasi.nic.in ( 20 July 2016.)

https://research-methodology.net/ (4 May 2020.) 